\title{
Mimořádná publikace o slovanských modernizacích
}

\author{
Agnieszka Janiec-Nyitrai (Budapešt)
}

Danuta Sosnowska (red.): Fabryka Słowian. Modernizacje. Warszawa: Wydział Polonistyki Uniwersytetu Warszawskiego, 2017. 408 s. ISBN 978-83-64111-07-5.

Svazek Modernizace zahajuje plánovanou tetralogii vycházející pod společným názvem Továrna Slovanů. Tato série je naplánována velice velkoryse a měla by obsahovat ještě tři svazky s následujícími tituly: Revize, Institucionalizace, Popularizace. Koncepce této série vznikla na půdě Ústavu západní a jižní slavistiky Varšavské univerzity. Jak uvádí vědecká redaktorka tohoto svazku Danuta Sosnowska, nápad pro vznik tohoto pozoruhodného projektu vyšel od současného vedoucího pracoviště, kroatisty a bohemisty Patrycjusze Pająka, (před rokem vydalo pražské nakladatelství Academia Pająkovu obsáhlou monografii Hrĩza v české literatuře) a autorkou samotného koncepčního uspořádání jednotlivých svazků je Anna Kobylińska, slovakistka, mj. autorka knihy Tropem Hermesa: przypadek stowackiego księdza, myśliciela i literata Jonáša Záborskiego (Varšava, 2012) a před rokem vydané knihy Peryferyjność. Habsbursko-stowiańska historia nieoczywista (společně s M. Falským a M. Filipowiczem; Krakov, 2017). Danuta Sosnowska vysvětluje také význam metaforického názvu celé série. Hlavní otázky, jež si jednotliví účastnici projektu soustavně kladli, totiž zněly: jakým způsobem tvůrci pracovali ve slovanských zemích s idejemi a vzory modernity? jaké „produkty“ byly výsledkem této práce?

Publikace je rozdělena do třinácti kapitol. První tvoří rozsáhlý úvod od vědecké redaktorky Danuty Sosnowské, následuje přepis mimořádně zajímavé diskuse „...̌̌ijeme mezi dvěma světy..." a pak kniha pokračuje v klasickém rozdělení do několika studií věnovaných české, slovenské, chorvatské, bulharské nebo slovinské tematice. Samotný tematický horizont výzkumu, na němž se podílela především mladší generace varšavské slavistiky, je široký.
Zásadní místo zaujímá právě samotný rozsáhlý úvod (s. 7-32) celé monografie, který lze označit za jakousi prolegomenu k celému svazku. Sosnowska signalizuje, že často se vracejícím tématem knihy je komunismus, který není chápán automaticky jako něco negativního: autoři si všímají, že zjednodušené nahlížení na toto téma (slovanský svět jako opožděný, „komunistický“, postkomunistický versus svět Západu jako pokrokový, prezentovaný v duchu idealizované svobody a demokracie) nikam nevede, právě naopak. Tato bipolarita je zavádějící a nepravdivá, vede k zhoubné idealizaci a nereflexivnímu přijímaní všech změn, k nimž po roce 1989 došlo. Autorka připomíná slova českého filozofa a esejisty Václava Bělohradského, který vnímá složitost tohoto problému a odmítá jakékoli reflexe zbavené přijetí všech modernizačních tendencí objevujících se po pádu komunismu. Podle Sosnowské si slovanská modernita zaslouží opětovnou, mnohostrannou a hlubší diskusi, protože už od šedesátých let minulého století docházelo $\mathrm{k}$ výrazné transformaci dosavadního způsobu uvažování o humanitních vědách a objektivní modely myšlení byly vystřídány perspektivistickým a individualistickým nahlížením na tuto problematiku.

Výchozí bod autorčiných úvah o otázkách modernizace, modernity a také v neposlední řadě samotného modernismu tvoří myšlení amerického badatele Marshalla Bermana, které obsáhl v knize All That Is Solid Melts Into Air: The Experience of Modernity (1982, polské vydání z roku 2006, české vydání zatím chybí). Berman přistupuje k modernitě a modernizacím jako k jevům nejednoznačným a složitým, plným paradoxů, a tímto tvoří vhodný kontext pro slovanské modernizace, jejichž jedním z distinktivních rysů je právě jistá pomíjivost, modernizační regresy 
a pochybnosti. Sosnowska uvádí důležité faktory, které lze považovat za nositele modernizace, jako např. industrializace, sekularizace, vzdělání, byrokratizace, technologizace, pluralismus hodnot a kulturních vzorců. Uvažuje také o rozdílech v chápání pojmů modernizace a modernismus. V Bermanových intencích rozlišuje modernizaci jako tendenci spojenou s praktickou stránkou lidského života, s praktickou realizací postulátů modernismu a sám pojem modernismus je spíše vyhraněn pro svět „vizí a ideji“ (s. 16). Autorka představuje mnoho př́kladů z oblasti architektury a na těchto př́kladech demonstruje vznik a pronikání modernizací do slovanského světa.

Po úvodních komentáŕích přibližujících smysl a rozmach knihy následuje diskuse „...Ž̌ijeme mezi dvěma suěty...", jíž se zúčastnili pracovníci varšavské slavistiky: kromě redaktorky svazku D. Sosnowské, která diskusi moderovala, také Patrycjusz Pająk, Anna Kobylińska, Maciej Falski, Robert Kulmiński, Aleksander Kaczorowski a Jasmina Šuler-Galos. Zařazení přepisu diskuse do této publikace lze považovat za mimořádně zdařilý nápad a vůbec za jednu z nejlepších a nejinspirativnějších částí celé monografie. Tato diskuse nebyla dopředu připravena a režírována, jak jsem se dozvěděla přímo od varšavských kolegů. Díky tomu se vyznačuje přirozeným, živým spadem řeči a není pouhou samoúčelnou prezentací erudovanosti či výčtem vědomostí jednotlivých účastníků debaty. Právě naopak - podařilo se zachytit pochybnosti a rozcestí různých slovanských modernizačních narací, a tímto dospět k inspirativním a podnětným zjištěním. Modernizace byly zachyceny v průsečíku národních a etnických diskursů, objevila se myšlenka, že technologický vývoj se nerealizoval vždy paralelně s vývojem národního uvědomění, že v některých kontextech (např. ve slovinském) modernizace nepřipomínala rovnou cestu vedoucí od potlačování národní identity (německý faktor) ke vzniku vlastního státu (s. 35). Obdobně složitá je tato problematika v rámci chorvatského nebo slovenského kontextu (mad’arský faktor). Pro účastníky diskuse se samotný problém chronologického uspořádání modernizačních tendencí modernismu jevil jako pozoruhodný. Důležitým milníkem byla první světová válka, která do slovanského světa přináší potřebu nalezení nového vztahu ke skutečnosti, hledání nového jazyka uměleckého a společenského dialogu, a nejde zde jen o pouhé kopírování modelu převzatého ze západního světa. Dalším podstatným aspektem, který byl během debaty podrobně rozebírán, byla otázka urbanizace a vůbec postavení velkoměst v rámci modernizačních procesů. $\mathrm{V}$ tomto ohledu byla vyzdvižena mimořádná úloha Prahy jako města, které nemuselo nic „dohánět“ ani se vyrovnávat s modernizačními tendencemi pramenícími z evropských center (např. Paříže), protože hlavní město českých zemí už od 19. století zaujímalo důležité místo na kulturní mapě Evropy. Vůbec postavení českých zemí ve srovnání s ostatními západními a jižními slovanskými státy je možné považovat za výjimečné (do detailů promyšlená i provedená masarykovská demokratická modernizace). Účastnící diskuse podtrhli také úlohu neslovanských metropolí (Vídeň, Budapešt') v konstruování modernizačních narací ve slovanském světě. Během diskuse se objevilo mnoho pozoruhodných myšlenek, např.: modernizace v sobě ne vždy nese pozitivně hodnocený náboj, podmínkou uvědomělé a „zralé“ modernizace musí být uvědomění si všech jejích možných důsledků, občas negativních či dokonce ničivých, nicméně podmínkou uplatnění pojmu modernizace by mělo být přesvědčení, že se jedná o změnu k lepšímu (s. 49-52). Badatelé odmítli chápání modernizace jako jakéhosi dohánění západních tendencí, protože tímto je již předem zvýrazněna nutnost existence nějakého konkrétního vzorce či matrice, podle níž by se mělo jednat, chovat se a uvažovat. Povšimli si také postupného vyčerpávání se modernistické formule, která podléhá neustálé technizaci, dehumanizaci a mění se v prázdnou, obsahu zbavenou.

Další blok, obsahující už jednotlivé studie věnované dílčím problémům konkrétních slovanských kultur, zahajuje stat Expanze forem. O jednom z aspektů modernizace české estetické myšlenky $v$ proni polovině 20. století (s. 65-104) od Anety Daszuty (uvádím překlady názvů jednotlivých studií; všechny části knihy jsou kromě doprovodných anglických resumé publikovány v polštině). Autorka analyzuje změny vnímání formy 
uměleckého díla, charakterizuje jednotlivé etapy zamlžování hranic mezi formou a obsahem a upozorňuje na kroky, které vedly k objevení existence objektivních pravidel estetického působení a vymezení pojmu estetické funkce, což bylo podstatné pro vývoj pražské strukturalistické školy. Daszuta přehledným a důsledným způsobem píše o zrání a emancipaci uměleckých forem a sleduje vývoj českého estetického myšlení v první polovině 20. století.

Český kontext se stává také předmětem analýzy v článku ,Ukázat jim, v čem je to lepši ‘. Projekt modernizace pohraniči v československé socialistické literatuře (s. 311-337) Karoliny Ćwiek-Rogalské. Autorka zkoumá modernizaci československého pohraničí v letech 1945-1948. Předmětem jejîho zájmu se stává pohraničí, které autorka chápe jako svéráznou laboratoř modernizačních technik, které byly následně po roce 1948 uplatňovány na území celého Československa. Analyzuje socrealistické romány (např. Řezáčův Nástup), ale také propagandistické publicistické texty a následně vymezuje čtyři hlavní aspekty modernizačního plánu pro tuto oblast: 1) výměna německého obyvatelstva, 2) „odněmčování“ prostoru, 3) nacionalizace, industrializace a kolektivizace zemědělství, 4) nahrazení ideje lokálnosti ideou univerzální socialistické společnosti.

Československým, a především českým kontextem, se zabývá také Aleksander Kaczorowski v článku Meandry modernizace: od pražského jara do normalizace (s. 338-363). Na modernizaci je zde nahliženo především jako na pokus o transformaci politického režimu v duchu demokracie. Stalinský model hospodářství a soustavného porušování občanské svobody vyvrcholil požadavky na změnu celého systému. Autor sleduje tento nepodařený pokus o modernizaci a liberalizaci politických poměrů, který nakonec vedl k ještě tvrdšímu omezování občanských práv v období normalizace.

Posledním textem věnovaným české kultuře je studie Roberta Kulmińského Domáci uměni (s. 364-383). Cílem článku, jak sám autor uvádí, je pokus o definici fenoménu domácího umění a vykreslení jeho stručných dějin, pokus o kritic- ké zhodnocení dosavadního výzkumu domácího umění a také úsilí o novou interpretaci v intencích Birminghamské školy (cultural studies), i přestože tato nová interpretace nedává vždy zcela uspokojivé výsledky.

Slovinskému kontextu je zasvěcena studie Marty Cmiel-Bażant Proměny slovinskojazyčné veřejné sféry v meziválečném obdobi (s. 105-141). Cílem studie je přiblížit proces formování se slovinské občanské společnosti v perspektivě modernizačních proměn. Článek zachycuje polarizaci stanovisek týkajících se různých vizí národa a jeho budoucnosti. Autorka pracuje s bohatým publicistickým materiálem, analyzuje způsob uchopení klíčových pojmů jako např. kultura, vývoj nebo pokrok v publicistice, dotýká se také důležitých otázek sekularizace veřejné sféry.

Další článek věnovaný slovinskému kontextu O rodokmenu slovinského sociálního realismu (s. 142-176) Jasminy Šuler-Galos přináší analýzu vybraných slovinských románů (A. Ingolič $L u$ karji, C. Kosmač Pomladni dan, I. Potrč Na kmetih, B. Zupančič Sedmina) - příkladů socrealistické tvorby v průsečíku historických a ahistorických kontextů modernizace. Pozoruhodným aspektem je zde přítomnost a návrat myšlenek Janeze Evangelisty Kreka (1865-1917), teologa a společenského aktivisty, který reprezentoval antimodernizační model ve slovinském myšlení. Článek prezentuje komplikovanost slovinských modernizačních tendencí.

Patrycjusz Pająk se ve studii Chorvatský filmový modernismus (s. 177-212) dotýká problematiky v zahraničních výzkumech zatím opomíjené, a to filmového umění. Článek přibližuje nejdůležitější díla tohoto proudu a charakterizuje tento estetický fenomén, který se vyvíjel až do sedmdesátých let 20. století. Autor definuje pojem „filmový modernismus“, vymezuje jeho stěžejní vlastnosti a následně sleduje vývoj tohoto projevu modernismu v Chorvatsku.

Mimoliterární tematice je zasvěcena rovněž další studie Co městský prostor řiká o modernizaci? Sarajevo a Bosna v obdobi habsburském (s. 213239) od Macieje Falského. Autor analyzuje modernizační politiku habsburské monarchie, kte- 
rá si stavěla za cíl přiblížit Bosnu ekonomickým, politickým, kulturním a v neposlední řadě také architektonickým normám středoevropského impéria. Falski hodnotí habsburské snahy jako ambivalentní - na jedné straně vedly ke zlepšení životních standardů v Bosně, ale na druhé straně bylo jejich důsledkem upozaděno kulturní islámské dědictví tohoto regionu. Na konkrétních příkladech Falski uvádí, jaký vliv měly habsburské modernizační tendence na vzhled sarajevského a bosenského prostoru.

Balkánskému kontextu je věnován také článek, který napsal Jerzy Molas: Forma přejeti moci jako překážka v modernizačnich procesech současného Srbska (s. 291-310), v němž autor na př́kladu současného Srbska vykresluje antimodernizační tendence, jejichž příčinou je válka o moc a vůbec chápání moci jako cíle veškerého lidského konání. Ti, kteří se k ní dostali, se pokoušejí si svůj vliv udržet za každou cenu.

Slovenské souvislosti objasňuje Anna Kobylińska v článku Fujara a pokrok. O paradoxech modernizace na Slovensku (Ján Lajčiak versus Alexander Matuška) (s. 240-265). Autorka podotýká, že otázka modernizace byla často analyzována s použitím klíče ideologického, národního a mnohdy byl její rytmus zjednodušeně diktován trajektoriemi politických změn. V článku je zdůrazněn složitý a nejednoznačný charakter slovenských modernizačních procesů, na něž autorka nahlíží, sestavujíc dvě symptomatická stanoviska prezentovaná předními slovenskými intelektuály: Jánem Lajčiakem (Slovensko a kultúra, 1920) a Alexandrem Matuškou (Hra na fujaru a pokrok, 1930). Slovenské modernizační procesy byly doprovázeny neustálým konfliktem konzervativních názorů s modernizačními trendy.

Sylwia Siedlecka analyzuje modernizační procesy probíhající v Bulharsku na příkladu proměn bulharského cirkusu. V článku Bulharský cirkus $v$ letech 1948-1983 jako modernizačni projekt (s. 266-290) pojednává o změnách bulharského společenského, intelektuálního a politického života na pozadí proměn bulharského cirkusu. Na cirkus se dívá jako na fenomén, který hluboce upoutal bulharské kulturní elity a stal se pozoruhodným předmětem výzkumu v intencích sovětské teorie zábavních žánrů. Před druhou světovou válkou byl cirkus chápán jako soukromý podnik zaměřený na zisk, v poválečném období se status cirkusu mění a cirkus se stává státní institucí, která byla zapojena do politického modernizačního projektu.

Monografie věnovaná slovanským modernizacím je mimořádně přínosnou a nabízí zcela nový úhel pohledu na zkoumanou tematiku. I přes tematickou pestrost se redaktorce podařilo vytvořit sjednocující model uvádějící jednotlivé, lokálnî podoby slovanských modernizací. Monografie si neklade za cíl poskytnout ucelený, encyklopedický obraz toho, jak probíhaly a probíhají modernizační procesy v konkrétních zemích, jedná se spíśe o sestavení komplexních sond prezentujících na pečlivě zvolených modelech polymorfní obraz jednotlivých modernizací: české, bulharské, chorvatské, slovenské aj. Tyto jednotlivé perspektivy tvoří model slovanské modernizace coby procesu složitého, nejednoznačného, mnohorozměrného a osobitého, zůstávajícího v komplikovaném vztahu k tendencím západním. Výzkum zpochybňuje často se objevující názory, že slovanské kultury pouze opakovaly a opakují vzorce přjejaté ze Západu, že se nacházejí v podružném vztahu k německému, francouzskému nebo anglickému kontextu. Publikace, která vznikla na Varšavské univerzitě, představuje pozoruhodný krok k dekonstrukci dosavadních mylných názorů a otevírá prostor k diskusi o smyslu a významu slovanských modernizací.

\section{PhDr. Agnieszka Janiec-Nyitrai, PhD.}

Ústav slovanské a baltské filologie

Univerzita L. Eötvöse

Múzeum krt. 4/D, 1088 Budapešt', Mad'arsko

janiec.nyitrai@gmail.com 